
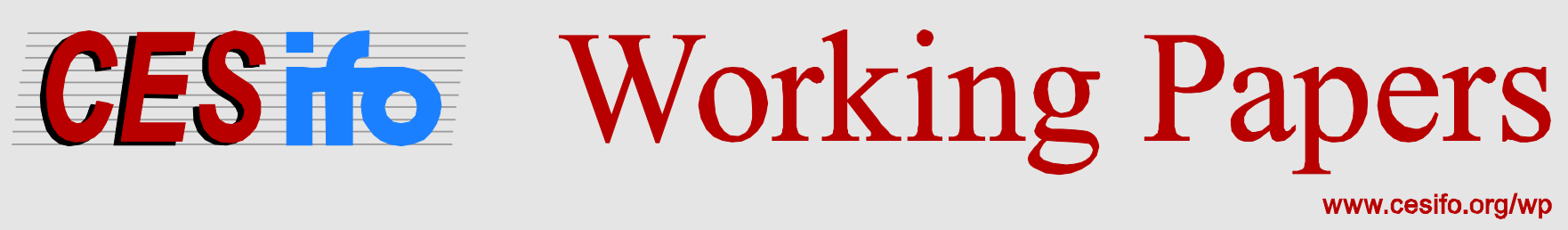

\title{
Household Vulnerability on the Frontline of Climate Change: The Pacific Atoll Nation of Tuvalu
}

\author{
Tauisi Taupo \\ Harold Cuffe \\ Ilan Noy
}

\section{CESIFO WORKING PAPER NO. 6128 \\ CATEGORY 10: ENERGY AND ClIMATE ECONOMICS \\ OCTOBER 2016}
An electronic version of the paper may be downloaded
- from the SSRN website: Www.SSRN.com
- from the RePEc website: Www.RePEc.org
- from the CESifo website: www.CESifo-group.org/wp




\title{
Household Vulnerability on the Frontline of Climate Change: The Pacific Atoll Nation of Tuvalu
}

\begin{abstract}
This paper investigates the vulnerability of households to climatic disasters in the low-lying atoll nation of Tuvalu. Small Island Developing States, particularly the atoll islands, are considered to be the most vulnerable to climatic change, and in particular to sea-level rise and its associated risks. We construct poverty and hardship profiles for households on the different islands of Tuvalu, and combine these with geographic and topographic information to assess the exposure differentials among different groups using spatial econometric models. Besides the observation that poor households are more vulnerable to negative shocks because they lack the resources to respond, we also find that they are also more likely to reside in highly exposed areas to disasters (closer to the coasts and at lower elevation) and have less ability to migrate (between and within the islands).
\end{abstract}

JEL-Codes: C310, I300, Q540, Q560.

Keywords: vulnerability, exposure, poverty, hardship, Tuvalu, atoll.

Tauisi Taupo

School of Economics \& Finance

Victoria Business School

Victoria University of Wellington

Wellington / New Zealand

tauisi.taupo@vuw.ac.nz
Harold Cuffe

School of Economics \& Finance

Victoria Business School

Victoria University of Wellington

Wellington / New Zealand

harold.cuffe@vuw.ac.nz

\author{
Ilan Noy* \\ School of Economics \& Finance \\ Victoria Business School \\ Victoria University of Wellington \\ Wellington / New Zealand \\ ilan.noy@vuw.ac.
}

*corresponding author

September, 2016

Sincere thanks to William Cochrane and John Gibson for their initial suggestions about the spatial models, to Christopher Edmonds for support and advice about the Pacific, and to audiences at the Pacific Update Conference. 


\section{Introduction}

The Pacific Island Countries (PICs), particularly low-lying islands, are confronted with a range of economic challenges by their smallness, remoteness and limited resources. These attributes raise the populations' vulnerability to economic shocks, and have hampered the islands' capabilities to match rising global living standards. Unfortunately, for households in these small atoll islands, many of the same geographical features that raise vulnerability to economic shocks, also contribute to heightened exposure and vulnerability to climatic shocks. These countries, in particular, have seen their circumstances change with the rise in sea levels, and the increase in damage caused by climatic hazards (in particular for this group of countries, cyclones). For the islands' poorest people, these dual economic and climatic threats pose an even greater challenge.

Even though poverty has been well researched globally, less attention has been given to Small Island Developing States (SIDS), and specifically to the PICs. This is surprising as the low-lying atoll island nations in the Pacific-Tuvalu, Kiribati and the Republic of the Marshall Islands-lie at the frontlines of climate change. The World Bank (2014) acknowledges that, "although the aggregate or macroeconomic impacts of negative shocks have been relatively well studied, much less is known about the impacts on household well-being, in large part because of data limitations." This paper aims to fill that gap by focusing on hardship and vulnerability facing households in the context of low-lying SIDS.

In this paper, we consider the case of Tuvalu, and in particular, the conditions of the population which are likely to relate to rising hardship resulting from climate change. To date, there has been no previous empirical country study on hardship and vulnerability in Tuvalu, or on any other Atoll country. Since disaster risk is the confluence of the hazard itself, exposure to the hazard, and the vulnerability of the exposed population, it is paramount to examine the current state of exposure and vulnerability in the affected countries, rather than focusing exclusively on the hazard triggers. This is our intent in this paper.

Specifically, we aim to explain how and which households in Tuvalu are particularly vulnerable and exposed to climatic shocks. Knowing these factors will assist in devising policies that reduce vulnerability and contribute to more effective Disaster Risk Management (DRM); a crucial and maybe the most important component of climate change adaptation. Using detailed expenditure survey data encompassing one third of the nation's population, the study is able to take a micro-perspective of the household, presenting empirical evidence of hardship and vulnerability to shocks that complements the macroeconomic analysis done elsewhere (e.g., Noy, 2015 and Cabezon et al., 2015). The work sheds further light on how households are facing and coping with disasters currently.

The paper proceeds as follows. The next section discusses the context of Tuvalu, section 3 provides a short survey of the relevant literature, section 4 discusses the measurement of poverty and hardship, section 5 discusses Tuvalu's exposure to disasters, section 6 outlines 
the empirical methodology, section 7 describes the data, section 8 explains the empirical results, while conclusions are presented

\section{Background}

The increasing frequency and intensity of disasters in the Pacific is well documented, and has contributed to the high (proportional) loss of human, natural, financial, social and physical capital in the region (Noy, 2016, World Bank, 2016). Tuvalu is a small low-lying country in the equatorial South Pacific. It has a population of about 11,000 people, scattered across nine low-lying atolls in the South Pacific. It is surrounded by an exclusive economic zone of 900,000 square kilometers $\left(\mathrm{km}^{2}\right)$ with a landmass of $25.9 \mathrm{~km}^{2}$ that rarely exceed five meters above sea level. Population density is highest in the capital Funafuti, which accounts for more than half of the population of Tuvalu. Tuvalu has a dual economy consisting of a small cash economy and a subsistence economy focussed on its traditional sectors of fishing and small scale agriculture. Government revenue largely comes from issuing fishing licenses to foreign fishing vessels, '.tv' internet domain revenues, remittances, and foreign aid (directly funding the budget, and through funding distributed to the Tuvalu Trust Fund). Families in the capital Funafuti are more dependent on cash income than those living in the outer-islands. People migrate from the outer-islands to the capital Funafuti in search of job opportunities, better access to health facilities, and better education. Food and non-food items are mostly imported except for fish and a limited supply of a very narrow range of fruits and vegetables. Most of the people currently residing in the capital are originally from the outer-islands, and have limited access to land and property ownership on Funafuti. Hence the reason for the high dependency on cash income in the capital. ${ }^{1}$

Most development and settlement in atoll islands occurs close to the coast, which is vulnerable to storms, floods and sea-level rise (World Bank, 2016). As a low-lying coral atoll, every high spring tide (King tide) floods properties situated in low lying-areas (including inner parts of the capital Funafuti) as the water rises through the coral ground, destroying household plantations. People typically adapt by raising gardens above the ground and cementing around and under crops to prevent intrusion of seawater. However, these precautions are not fully adequate, and the combination of high tides and storms continue to pose considerable threat to households living at low elevation and near the coastline. Adding to the problem is the fact that the sea-level rise at Funafuti is three times above the global average between 1950 and 2009 (Becker et al., 2012), and this trend will likely worsen over time (Yamano et al., 2007). Appendix C shows the increasing trend of sea levels in Tuvalu.

\footnotetext{
${ }^{1}$ According to the 2012 Census, only $17.7 \%$ of the people living on Funafuti are local Funafuti people, while the rest are without land ownership, and are renting houses from the locals. Based on the 2012 Census, $84.5 \%$ of rental houses in Tuvalu are on Funafuti.
} 


\section{Poverty and Hardship}

There is a broad literature on poverty and vulnerability, but very limited focus on SIDS, especially low-lying islands like Tuvalu. Jha et al. (2009) measure the extent of vulnerability as expected poverty using cross-sectional data from a household survey in Fiji and find that vulnerability is largely a rural phenomenon. Similarly, Jha and Dang (2010) use crosssectional data from the 1996 Household Survey for Papua New Guinea (PNG) to assess household vulnerability to poverty in PNG. These papers on Fiji and PNG do not focus on geographical and climatic factors, and the geographical settings, resource base and economic characteristics of these volcanic Pacific islands are different from low-lying atoll islands such as Tuvalu.

We focus on poverty and exposure since they are vital indicators of how vulnerable, resilient and responsive households are to crises. According to Haughton and Khandker (2009), vulnerability is defined as the risk of falling into poverty in the future, even if the person is not necessarily poor at present; it is often associated with the effects of "shocks" from disasters and economic crises. Dercon (2005) outlines, for Sub-Saharan Africa, the links between risk and vulnerability to poverty thus highlighting the vital role played by them in determining people's livelihoods and opportunities to escape poverty. ${ }^{2}$

Abject poverty in Tuvalu is rare or non-existent, partly because of the culture and community traditions. Help and support are common from families, communities, religious groups and friends. Poverty, as a term, is therefore not frequently used in many of the PICs that have similar circumstances and cultural practices. ${ }^{3}$ We compare poverty levels from the three household surveys from different years to examine how poverty levels have changed over time. We follow Ravallion (1998) and Haughton and Khandker (2009) in defining and measuring poverty. Hence, we define poverty incidence as the percentage of households who fall below the food consumption level. Hardship is similarly defined for households whose expenditures fall below the benchmark food and non-food consumption levels. The vulnerability to poverty incidence refers to the percentage of households who are above the hardship threshold, but are vulnerable to falling under the as a result of negative shocks (measured as $110 \%$ of the hardhip level). ${ }^{4}$ In addition, we also include the non-resilience

\footnotetext{
${ }^{2}$ Recent papers on Asian and African poverty and vulnerability are Dasgupta and Baschieri (2010); Dutta et al. (2011); Echevin (2014); a recent comprehensive survey of this literature is Hallegatte et al. (2016).

${ }^{3}$ Abbott and Pollard (2004) emphasise that 'hardship' is a more acceptable terminology. The World Bank (2014) also argues that "the label of poverty is considered culturally inappropriate because it is viewed as implying a failure of traditional, community-based safety nets". Below we used hardship and poverty interchangeably, to mean "living with less than expected to meet both required food consumption and nonfood essentials."

${ }^{4}$ In practice, this includes all those below a threshold that is $10 \%$ higher than the Basic Needs Poverty Line (BNPL). The BNPL was calculated based on Ravallion (1998), and in line with Tuvalu Statistics Office's policy. The hardship threshold is the sum of the Food threshold and the Non-Food threshold. The Food component was calculated from a basket of essential basic food items that is estimated to be equivalent to the widely used nutritional requirement for good health of 2,100 calories per person per day suggested by the Food and Agricultural Organisation (FAO) of the United Nations. The Non-Food threshold is the average Non-Food Expenditure by households in the lowest 3 deciles. The Non-Food threshold is calculated differently for rural
} 
incidence which refers to the percentage of households who are still vulnerable to negative shocks and could potentially fall into poverty. This non-resilience threshold is determined as those households living below 10 USD (purchasing power parity) per person per day measure that is believed to be necessary to achieve the degree of economic stability and resilience to shocks (see World Bank, 2013). ${ }^{5}$ Therefore, we identify four thresholds: poverty (food), hardship (food and non-food), vulnerability (10\% above hardship), and non-resilience (10 USD).

Figure 1 shows that the poverty incidence has increased by less than 2\% from 2004/5 to 2010 at all levels of national, urban and rural. Hardship incidence has also increased by around 2\% from 2004/5 to 2010 for the urban population, but decreased by $2.22 \%$ for the rural one. The 1994 hardship incidences from Abbott and Pollard (2004) are higher at all three levels. Poverty incidence is usually higher in the urban area when compared with the rural one. ${ }^{6}$ Some possible reasons leading to a higher urban poverty incidence are the overcrowding in the urban households and high wage unemployment. ${ }^{7}$

Figure 1: Incidence of poverty and hardship in Tuvalu

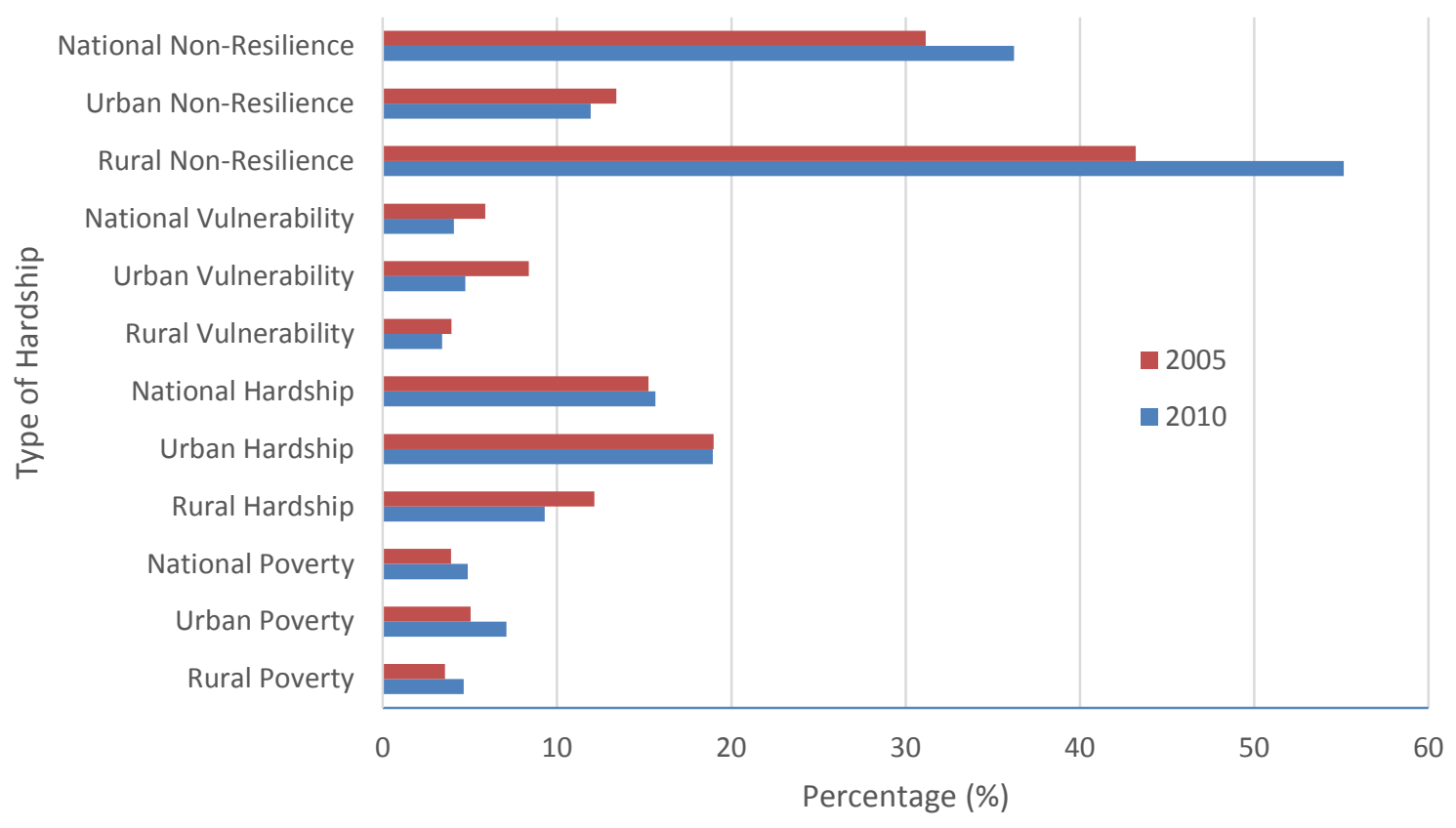

Source: Authors' calculations, on data from 2004/5 \& 2010 Household Income \& Expenditure Survey (HIES).

Except for the non-resilience measure, we do not observe dramatic increases in poverty, hardship and vulnerability in the five years separating the two surveys. Worryingly,

and urban (Funafuti) areas as the non-food expenditure, especially housing, is quite different between the regions. Expenditure is derived as the sum of Food Expenditure and Non-Food Expenditure.

${ }^{5}$ USD refers to United States Dollars while AUD refers to Australian Dollars.

${ }^{6}$ This is also reported by Abott and Polard (2004) but unlike the case for Fiji reported in Jha et al. (2009).

${ }^{7}$ Other possibilities can be traced to the availability of more employment in the rural sector from the island council, clinics, island development projects, and small scale businesses (after the collapse of the Tuvalu Cooperative Society). Informal work allocation in the outer-islands is also more equally distributed amongst families and may not rely educational qualification as much as in the urban area of Funafuti. 
however, we observe higher incidence of all the lower threshold measures (poverty, hardship and vulnerability) in the urban areas relative to rural ones. As the urban population is increasing faster than the rural one (mostly because of rural-urban migration), this may indicate a trend decrease in well-being. However, the non-resilience incidence is higher in the rural areas, and has increased significantly, between 2005 and 2010, exclusively in the rural area by $10 \%$, while it decreased in the urban setting. These tabulations demonstrate that more severe poverty is found in the urban region, but that the well-being in the rural areas is also potentially fragile as households do not have sufficient resources to cushion against disaster shocks (such as cyclone Pam that hit many of the outer islands in March 2015).

Appendix $D$ displays maps of hardship incidences in the islands for different villages, we are able to construct these maps as households have been geo-located in the surveys. It is evident that households close to central areas have lower hardship incidences. We also observe that in the capital Funafuti, hardship incidence is much higher for those households living in the narrow parts of the island to the North and South and further away from the central area. Tuvalu's main atoll Funafuti is just $12.5 \mathrm{~km}$ long and no more than 800 meters wide. $^{8}$

\section{Exposure to Natural Disasters}

Many households in low-lying islands are geographically exposed to climatic disasters, and in this section we quantify this exposure in Tuvalu. Figure 2 analyzes the vulnerability of households to disasters for all the islands. ${ }^{9}$ The islands were divided into three groups, i.e. the Northern Islands (Nanumea, Nanumaga and Niutao), the Central Islands (Nui, Nukufetau, Vaitupu and Funafuti) and the Southern Islands (Nukulaelae and Niulakita). In terms of vulnerability and exposure to climatic disasters, for each island we measured the proximity to hazard locations in reference to households living within 100 meters in land width (i.e. narrow parts of the island), households living within 20 meters of the pits ${ }^{10}$ and ponds, households living within 100 meters of the east coast, households living within 100 meters of the coastline, households living less than 5 meters of elevation, households living in non-concrete houses, and households who have less than 16,000 liters of water storage capacity. ${ }^{11}$

Figure 2: Household vulnerability and exposure indicators to disasters by island.

\footnotetext{
${ }^{8}$ Authors' calculations from digitized maps.

${ }^{9}$ Niulakita, the smallest island, was excluded from the household survey.

${ }^{10}$ Borrow pits (we will refer to it as "pits" onward) were created by digging/borrowing of soil by the American military from parts of the island of Fongafale (Funafuti) during World War II in order to construct the airplane runway. The 20 meters to the pits is based on the assumption that during kind tides, a house within that range will most likely be flooded.

${ }^{11}$ The assumed 16,000 liters water capacity storage threshold used is the median of household water storage for all households surveyed in the 2010 HIES, which is assumed to be sufficient if water is used efficiently.
} 


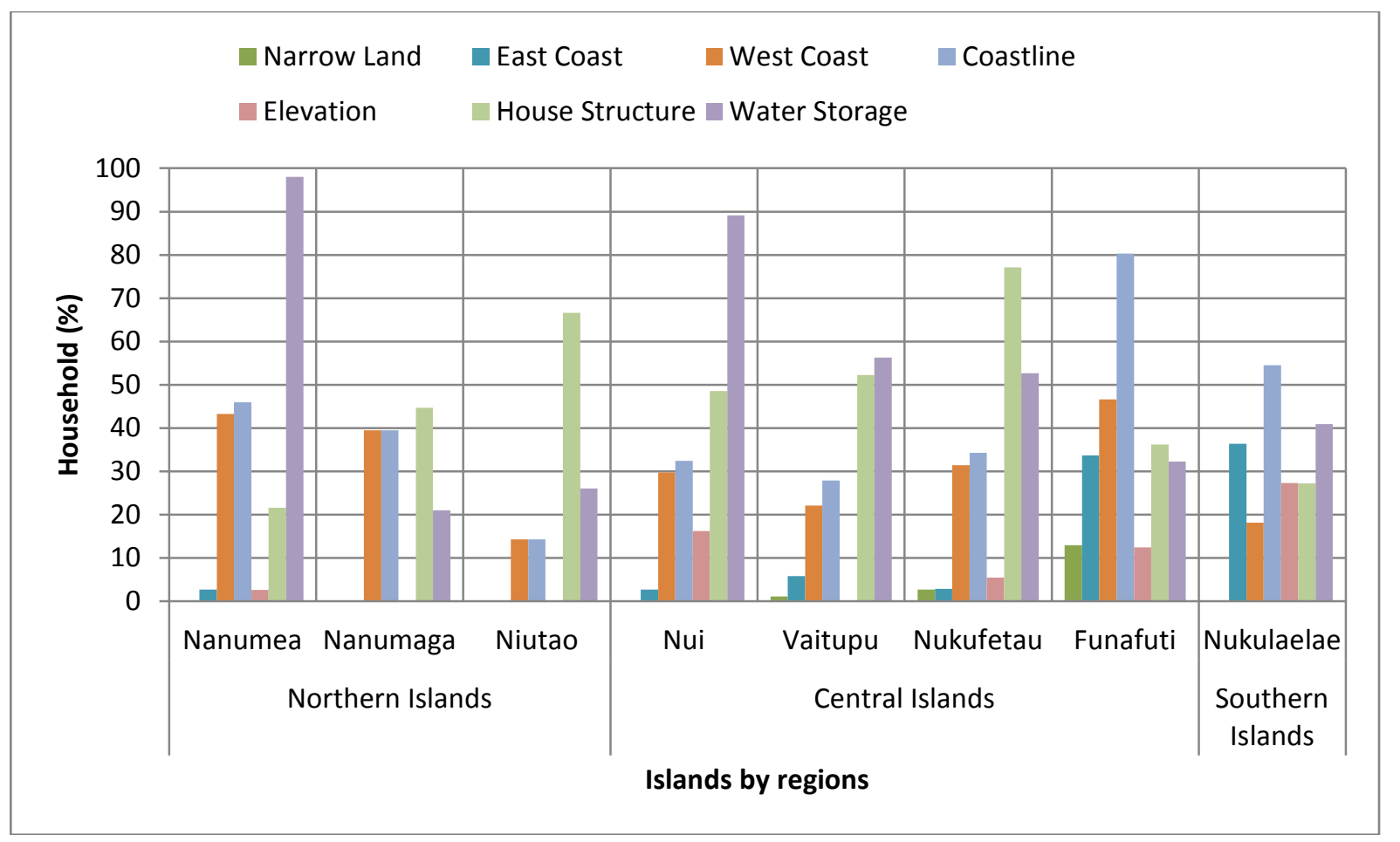

Source: Author's calculations from 2010 Household Income \& Expenditure Survey (HIES) data.

The Northern Islands have higher exposure indices (compared to the Central and Southern Islands). The Central Islands have the highest percentage of households residing in narrow parts of the islands which are prone to disasters. On the capital Funafuti, $13 \%$ of households reside in narrow parts of the island which are exposed to storms, while $9.3 \%$ of households live beside pits and ponds which are prone to flooding during king tides. ${ }^{12}$ While no surveyed households in the Northern and Southern Islands reside fewer than 50 meters to the east coastline, it is not uncommon in the Central Islands, particularly Funafuti, with $17.2 \%$ of households living within 50 meteres of the coast. Many of the households in Nukulaelae (27.3\% of households), Nui (16.2\% of households), and Funafuti (12.5\%) reside at low elevation compared to the other islands. ${ }^{13}$ Regarding house structures, $44.7 \%$ of households have concrete houses which are better able to withstand strong winds and storm surges. However, regarding vulnerability to droughts, Nanumea and Nui have the highest insufficient water storage capacity. Figure 3 displays exposure in terms of elevation and proximity to coastlines by income classification (hardship/non-hardship). In general, while we observe some differences across the two groups: the non-hardship group is

\footnotetext{
${ }^{12}$ This problem has been mostly solved in 2015 by the Tuvalu Borrow Pits Remediation (BPR) project funded under the NZ Aid Programme, where ten borrow pits on Fongafale island were filled with sand except for Tafua pond to the north eastern side of the airstrip, which is a natural pond. It is yet to be seen if we will observe any future flooding in these filled up pits.

${ }^{13}$ This was obvious since Nui and Nukulaelae were flooded during the 2015 Cyclone Pam. However, the three islands Nanumaga, Niutao and Vaitupu who have higher elevation, did not experience flooding during Cyclone Pam, but only storm surge and coastal intrusion of sea waves from the western side. All islands build their harbour and houses on the western side of the island away from easterly winds, but a cyclone that strikes from the west side will badly hit most islands without lagoons and islets on the west as shields.
} 
somewhat more likely to live closer to the coast, but also in higher elevation. However, these differences are not consistent across islands and do not represent a statistically significant difference across these samples.

Figure 3: Household exposure.

Source: Authors' calculations from the 2015 HIES.

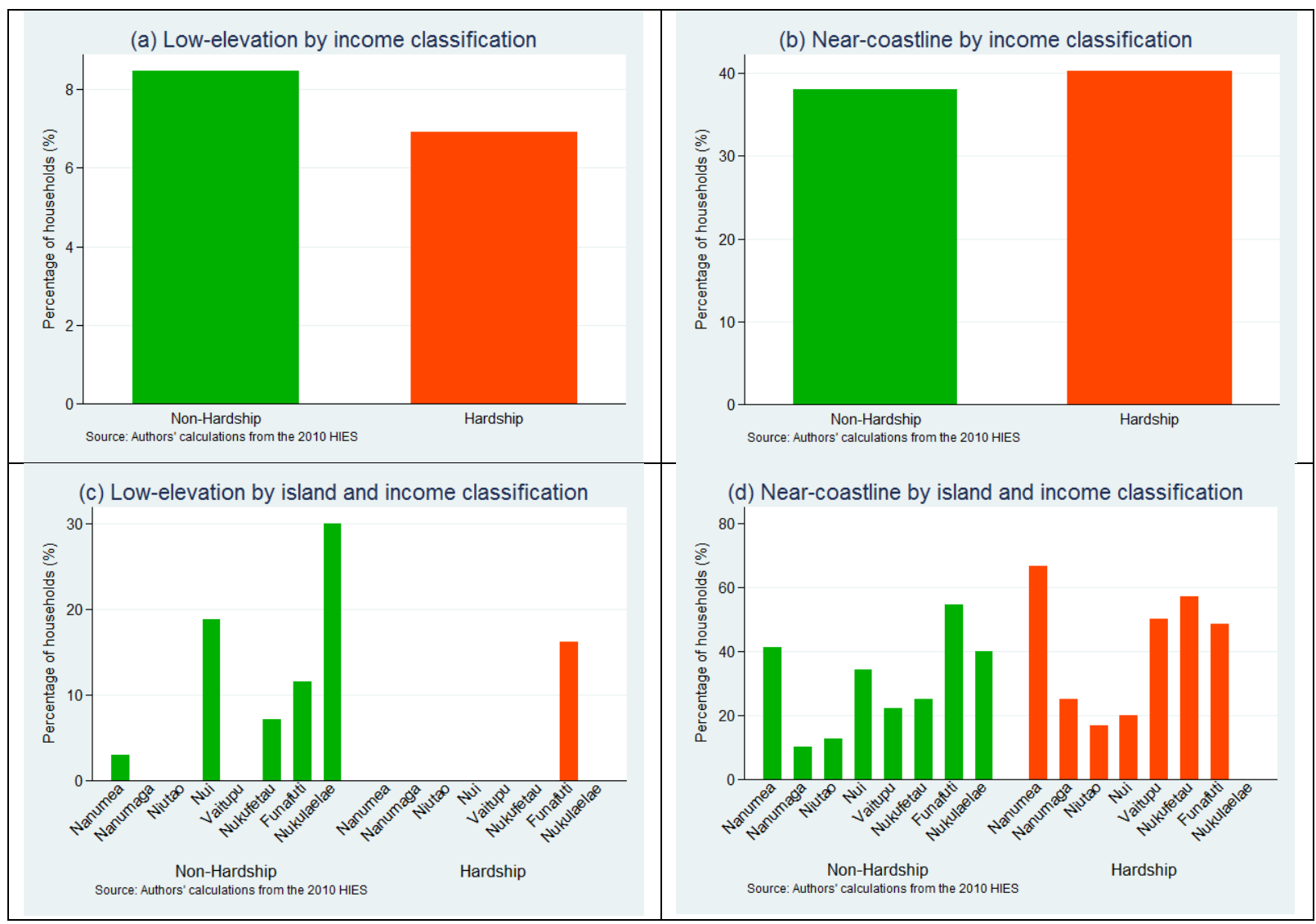

Source: Authors' calculations from the 2015 HIES.

\section{Estimation Methods}

Olivia et al. (2009) argued that ignoring spatial dependencies across households, when using household survey data to estimate poverty levels, may lead to misleading estimates. Gibson and McKenzie (2007) further argue for the importance of using precise geo-location systems (e.g., GPS) to determine locations and distances between households. Their work suggests that distance from households to numerous geographic features like roads, markets, schools, and health clinics might be important in understanding poverty. Olivia et al. (2011) also outlined the importance of identifying environmental factors that influence poverty. Theoretical links are discussed in World Bank (2007) while Jalan and Ravallion (1998, 2002) provide empirical evidence linking the poor to geographical variables. Gibson and Rozelle (2002) used a probit estimation to show that poverty in Papua New Guinea (PNG) is primarily rural and is associated with communities with poor access to services, markets, and transportation. 
Spatial regression methods permit us to account for spatial effects or spatial dependence between observations, where spatial data were geo-coded for location. Generally, spatial dependence refers to a situation where values observed at one household location, say household $i$, depend on the values of neighboring households at nearby locations. Suppose we let households $i$ and $j$ represent neighbors, then the value taken by $y_{i}$ depends on that of $\mathrm{y}_{j}$. The spatial matrix identifies neighbors or spatially close households and their effects, and the need to account for the spatial dependence in the regression model. ${ }^{14}$ Spatial models, similar to the one estimated here, have been used in other contexts in real estate economics, economic geography, and urban and regional science.

LeSage and Pace (2009) outline the two main motivations for estimation of spatial dependence. First, spillovers stemming from congestion effects may warrant estimation of spatial dependence models, as neighbors' outcomes directly impact one another. Second, spatial models may reduce estimation bias stemming from unobserved omitted variables which exhibit spatial dependence. ${ }^{15}$ Following this literature, ${ }^{16}$ we employed four spatial models (as described in the equations below) and also include the standard Ordinary Least Squares (OLS) model for comparison. ${ }^{17}$ The standard OLS model or the non-spatial linear regression model takes the form

$Y_{i}=\alpha_{i} l_{N}+X_{i} \beta_{i}+\varepsilon_{i}$

where $Y$ is the income that denotes an $N \times 1$ vector consisting of one observation on the dependent variable for the $N$ units (households) in the sample $(i=1, \ldots, N), \mathrm{l}_{N}$ is an $N \times 1$ vector of ones associated with the constant term parameter to be estimated, $X$ denotes an $N \times K$ matrix of exogenous explanatory variables, $b$ is an associated $K \times 1$ vector with unknown parameters to be estimated, and $\varepsilon=\left(\varepsilon_{1}, \ldots, \varepsilon_{N}\right)^{T}$ is a vector of disturbance terms, where $\varepsilon_{\mathrm{i}}$ is assumed to be independently and identically distributed for all with zero mean and variance $\sigma^{2}$.

We employ Maximum Likelihood estimation for the family of spatial regression models including Spatial Autoregressive Model (SAR), Spatial Error Model (SEM), Spatial Durbin Model (SDM) and Spatial Autocorrelation Model (SAC). The SAR, SEM, SDM and SAC models take the specifications described in (2), (3), (4) and (5), respectively, below.

$Y_{i}=\alpha_{i} l_{N}+\rho W Y_{i}+X_{i} \beta_{i}+\varepsilon_{i}$

\footnotetext{
${ }^{14}$ ArcGIS was used for geo-coding of locations (households, schools, hospitals/clinics, etc), creating a digitized map for all islands and islets in Tuvalu. These were then used in STATA for the empirical analysis.

${ }^{15}$ LeSage and Pace (2009) state that "omitted variables may easily arise in spatial modeling because unobservable factors such as location amenities, highway accessibility, or neighborhood prestige may exert an influence on the dependent variable. It is unlikely that explanatory variables are readily available to capture these types of latent influences."

${ }^{16}$ See Anselin (1988), Elhorst (2014), Gibson and McKenzie (2007), Gibson and Rozelle (2002), Jalan and Ravallion (1998 and 2002), LeSage and Pace (2009), and Olivia et al. (2011).

${ }^{17}$ Elhorst (2014) shows the relationship between the different spatial dependence models for cross-section data.
} 
$Y_{i}=\alpha_{i} L_{N}+X_{i} \beta_{i}+u_{i}, \quad$ where $u_{i}=\lambda W u+\varepsilon_{i}$

$Y_{i}=\alpha_{i} L_{N}+\rho W Y_{i}+X_{i} \beta_{i}+W X_{i} Y+\varepsilon_{i}$

$Y_{i}=\alpha_{i} l_{N}+\rho W_{1} Y_{i}+X_{i} \beta_{i}+u_{i}, \quad$ where $u_{i}=\lambda_{i} W_{2} u_{i}+\varepsilon_{i}$

WY denotes the endogenous interaction effects among the dependent variable, and Wu the interaction effects among the disturbance term of the different units. The parameter $\rho$ is the so-called spatial autoregressive coefficient, while $\lambda$ is the spatial autocorrelation coefficient. There is no spatial dependence in the vector of cross-sectional observations $Y$ if $\rho$ takes the value of zero, thus yielding to the OLS model. $W$ is a non-negative $N \times N$ matrix describing the spatial configuration or arrangement of the units in the sample. The spatial weight matrices will then be 'row-standardized' where the weights need to sum up to one on each row, or otherwise equal to zero if there are no neighbors. ${ }^{18}$ The spatial weight matrix is defined as $W$ with elements $w_{i j}$ indicating whether observations $i$ and $j$ are spatially close, that is, $w_{i j}=1 / d_{i j}$ for neighbors where $d_{i j}$ is the distance between households $i$ and $j$ (inverse distance weights) and otherwise $w_{i j}=0$. Beyond a certain distance, we assume that there are no spatial effects.

We also employ a binary outcome model (a probit) that is estimated with the dependent variable as the probability of a household experiencing hardship and an identical set of independent variables used in the non-spatial OLS regression. Following Gibson and Rozelle (2002) and Jha et al. (2009), the dependent variable in this case is a dummy defined as

$\operatorname{Pr}\left(\operatorname{Pov}_{i}=1 \mid x_{i}\right)=F(X \beta)$

where $X$ is the vector of explanatory variables, $\beta$ is the set of parameters reflecting the impact of changes in on the probability. The $F(X \beta)$ is the cumulative distribution function (CDF) of the standard normal distribution. This approach estimates the households' probability of being poor, but includes no spatial component. We estimate the limited dependent variable model as a robustness check and since this is a common methodology in the literature.

\section{Data}

We utilize the Household Income and Expenditure Survey (HIES) data collected by the Central Statistics Division (CSD) of the Tuvalu Government for the years 2004/5 and 2010, which provides information on income and expenditures of households in Tuvalu. The 2010 HIES collected information from 541 households from all of the islands except for Niulakita ${ }^{19}$ while the 2005 HIES has a sample of 459 households. The households surveyed were randomly selected. The surveys represent around $33 \%$ of the population of Tuvalu; this large

\footnotetext{
${ }^{18}$ For our case, every household has at least one neighbor. Therefore, each row sums up to 1.

${ }^{19}$ The smallest island in Tuvalu with only four households (based on the 2012 Census).
} 
sample was necessary for accuracy as a representative sample at the national level. The sample selection was spread proportionally across all the islands with a selection process that listed each dwelling on the islands by their geographical position and systematically skipped through the list to achieve the $33 \%$ randomly selected sample.

For spatial analysis purposes, we used the 490 households with available Global Position System (GPS) locations for the 2010 HIES. The survey includes both individual and household variables. For our model, the dependent variable used both income and expenditure as a measure of poverty and welfare. Additionally, we used a set of control variables of household characteristics and geographical measurments.

Income per capita was used as the measure of welfare for the non-spatial and spatial regressions while expenditure per capita was used to determine hardship lines where an acceptable minimum standard of that indicator was established (Ravallion, 1998; Pradhan and Ravallion, 2000; Ravallion, 1996a, 1996b). We also used the binary indicator (hardship and non-hardship) as our dependent variable regressing on the same household characteristics used in the spatial and non-spatial regressions. Appendix Table A provides more description of the dependent and independent variables and their sources.

\section{Estimation Results and Discussions}

Table 2 compares the means of selected variables and indicators for the years 2004/5 and 2010. Household size on average is higher in the urban areas. Education levels of heads of households increased between the two surveys with more educated household heads in the urban area; though the differences are not very large. Urban households have a higher number of dependents, depend more on cash income, live in areas of lower elevation, narrower land width, in higher density (i.e. more than three times compared to rural), and closer to coastlines. Although those in the urban area have less access to land, house ownership, fisheries and agricultural activities, they are have better access to the economic opportunities present in the capital.

Table 2: Comparing means of selected indicators

\begin{tabular}{lccc|ccc}
\hline & \multicolumn{3}{c}{$\mathbf{2 0 0 4 / 5}$} & \multicolumn{3}{c}{$\mathbf{2 0 1 0}$} \\
\cline { 2 - 7 } & Rural & Urban & National & Rural & Urban & National \\
\hline Household size & 4.839 & 6.301 & 5.409 & 4.721 & 6.757 & 5.420 \\
& $(2.4228)$ & $(3.2771)$ & $(2.8739)$ & $(2.5089)$ & $(3.6047)$ & $(3.0839)$ \\
\hline Depend & & & 1.993 & 2.408 & 2.136 \\
& & & & $(1.4869)$ & $(2.0828)$ & $(1.724)$ \\
\hline Age & 52.157 & 46.245 & 49.851 & 51.724 & 47.461 & 50.260 \\
& $(13.9806)$ & $(12.8297)$ & $(13.8336)$ & $(12.3203)$ & $(12.1625)$ & $(12.4203)$ \\
\hline Gender & 0.782 & 0.754 & 0.771 & 0.817 & 0.763 & 0.798 \\
& $(0.4135)$ & $(0.4317)$ & $(0.4204)$ & $(0.3869)$ & $(0.4263)$ & $(0.4013)$ \\
\hline Marital status & 0.782 & 0.849 & 0.808 & 0.817 & 0.810 & 0.815 \\
& $(0.4135)$ & $(0.3588)$ & $(0.3940)$ & $(0.3869)$ & $(0.3929)$ & $(0.3886)$ \\
\hline Ethnic & 0.950 & 0.960 & 0.954 & 0.965 & 0.934 & 0.955 \\
& $(0.2183)$ & $(0.1943)$ & $(0.2091)$ & $(0.1816)$ & $(0.2474)$ & $(0.2068)$ \\
\hline Literate & & & & 0.702 & 0.928 & 0.780 \\
& & & & $(0.4577)$ & $(0.2575)$ & $(0.4143)$ \\
\hline
\end{tabular}




\begin{tabular}{|c|c|c|c|c|c|c|}
\hline Education years & $\begin{array}{c}7.689 \\
(3.2736) \\
\end{array}$ & $\begin{array}{c}9.564 \\
(5.4007) \\
\end{array}$ & $\begin{array}{c}8.420 \\
(4.3246) \\
\end{array}$ & $\begin{array}{c}7.851 \\
(3.3533) \\
\end{array}$ & $\begin{array}{l}10.526 \\
(4.184) \\
\end{array}$ & $\begin{array}{c}8.770 \\
(3.8708) \\
\end{array}$ \\
\hline Work & & & & $\begin{array}{c}0.275 \\
(0.4474)\end{array}$ & $\begin{array}{c}0.609 \\
(0.4893)\end{array}$ & $\begin{array}{c}0.390 \\
(0.4883)\end{array}$ \\
\hline House owner & & & & $\begin{array}{c}0.839 \\
(0.3680)\end{array}$ & $\begin{array}{c}0.526 \\
(0.5007) \\
\end{array}$ & $\begin{array}{c}0.731 \\
(0.4435) \\
\end{array}$ \\
\hline Urban & $\begin{array}{c}0.000 \\
(0.0000)\end{array}$ & $\begin{array}{c}1.000 \\
(0.0000)\end{array}$ & $\begin{array}{c}0.389 \\
(0.4882)\end{array}$ & $\begin{array}{c}0.000 \\
(0.0000)\end{array}$ & $\begin{array}{c}0.952 \\
(0.2129)\end{array}$ & $\begin{array}{c}0.390 \\
(0.4883)\end{array}$ \\
\hline Distant to the central & & & & $\begin{array}{c}256.016 \\
(136.8334)\end{array}$ & $\begin{array}{c}1.157 \\
(1.4703)\end{array}$ & $\begin{array}{c}168.437 \\
(164.1853)\end{array}$ \\
\hline Distant primary & & & & $\begin{array}{c}0.399 \\
(0.4161)\end{array}$ & $\begin{array}{c}0.959 \\
(1.3881)\end{array}$ & $\begin{array}{c}0.592 \\
(0.9185) \\
\end{array}$ \\
\hline Distant to the hospital & & & & $\begin{array}{c}0.450 \\
(0.4580)\end{array}$ & $\begin{array}{c}1.261 \\
(1.3193)\end{array}$ & $\begin{array}{c}0.728 \\
(0.9389)\end{array}$ \\
\hline Distant to the government & & & & $\begin{array}{c}256.1234 \\
(136.8127)\end{array}$ & $\begin{array}{c}1.348 \\
(1.5264)\end{array}$ & $\begin{array}{c}168.609 \\
(164.1447)\end{array}$ \\
\hline Land width & & & & $\begin{array}{c}2.1465 \\
(2.2384)\end{array}$ & $\begin{array}{c}0.347 \\
(0.2125)\end{array}$ & $\begin{array}{c}1.528 \\
(2.0080)\end{array}$ \\
\hline Distant to the coast & & & & $\begin{array}{c}0.201 \\
(0.1570)\end{array}$ & $\begin{array}{c}0.096 \\
(0.0688)\end{array}$ & $\begin{array}{c}0.165 \\
(0.1423)\end{array}$ \\
\hline Distant to the borrow pits & & & & $\begin{array}{c}68.811 \\
(58.3149)\end{array}$ & $\begin{array}{c}0.382 \\
(0.4024)\end{array}$ & $\begin{array}{c}45.305 \\
(57.3436)\end{array}$ \\
\hline Elevation & & & & $\begin{array}{c}10.659 \\
(2.7163)\end{array}$ & $\begin{array}{c}6.634 \\
(1.5654)\end{array}$ & $\begin{array}{c}9.277 \\
(3.0559)\end{array}$ \\
\hline Rainfall & & & & $\begin{array}{c}2382.575 \\
(525.7113)\end{array}$ & $\begin{array}{l}2765.869 \\
(83.8429)\end{array}$ & $\begin{array}{c}2514.235 \\
(465.6705)\end{array}$ \\
\hline Density & & & & $\begin{array}{c}858.487 \\
(1080.921)\end{array}$ & $\begin{array}{l}3349.086 \\
(594.264)\end{array}$ & $\begin{array}{c}1713.998 \\
(1512.862)\end{array}$ \\
\hline Observations & 280 & 179 & 459 & 323 & 169 & 492 \\
\hline
\end{tabular}

Source: Authors' estimations from 2004/5 and 2010 HIES data. Standard deviations in parentheses.

The diagnostic tests for spatial dependence of the spatial models were carried out using the Moran's I and Lagrange Multiplier tests. ${ }^{20}$ Moreover, the Moran's I test statistic indicates the strength of the spatial autocorrelation of the residuals while the simple Lagrange Multiplier (LM) tests for missing spatially lagged dependent variable and the Robust LM tests for error dependence in the possible presence of a missing lagged dependent variable. The diagnostic tests provide most support to the SDM specification; as they indicate the presence of spatial dependence for all levels. $\rho$ is the spatial autoregressive coefficient while $\lambda$ is the spatial autocorrelation coefficient. The values of $R^{2}$ indicate the goodness of fit of the model.

Table 3: Estimation Results - LHS income per person (2010)

\begin{tabular}{|c|c|c|c|c|c|c|c|}
\hline & OLS & SLM & SEM & SAC & $\begin{array}{c}\text { SDM } \\
\text { (National) }\end{array}$ & $\begin{array}{c}\text { SDM } \\
\text { (Urban) }\end{array}$ & $\begin{array}{c}\text { SDM } \\
\text { (Rural) }\end{array}$ \\
\hline hholdsize & $\begin{array}{c}-0.114^{* * *} \\
(0.00978)\end{array}$ & $\begin{array}{c}-0.114 * * * \\
(0.00971)\end{array}$ & $\begin{array}{l}-0.114^{* * *} \\
(0.00971)\end{array}$ & $\begin{array}{c}-0.114^{* * *} \\
(0.00970)\end{array}$ & $\begin{array}{c}-0.113 * * * \\
(0.00964)\end{array}$ & $\begin{array}{c}-0.0935 * * * \\
(0.0133)\end{array}$ & $\begin{array}{c}-0.125 * * * \\
(0.0145)\end{array}$ \\
\hline age & $\begin{array}{c}0.00741 * * * \\
(0.00249)\end{array}$ & $\begin{array}{c}0.00751 * * * \\
(0.00247)\end{array}$ & $\begin{array}{c}0.00752^{* * *} \\
(0.00247)\end{array}$ & $\begin{array}{c}0.00757^{* * *} \\
(0.00247)\end{array}$ & $\begin{array}{c}0.00811^{* * *} \\
(0.00250)\end{array}$ & $\begin{array}{c}0.0168 * * * \\
(0.00427)\end{array}$ & $\begin{array}{c}0.00917^{* * *} \\
(0.00327)\end{array}$ \\
\hline
\end{tabular}

${ }^{20}$ The Moran's I test statistic is used to test if the data has spatial dependence. According to Olivia et al. (2009), the Moran's I for a row standardized spatial matrix where e is a vector of OLS residuals and W is the spatial weight matrix, asymptotically normally distributed with an expected value of $-1 /(\mathrm{N}-1)$ and its statistical significance can be evaluated from a standardized normal table. It is expressed as I=e'We/e'e. The Lagrange Multiplier (LM) tests for SEM and SAR whether $(\lambda=0)$ and $(\rho=0)$. The Robust LM tests were also developed by Anselin et al. (1996) to cater for the presence of both SEM and SAR (which is a weakness for the LM test as LM and $\mathrm{LM}_{\rho}$ have power against the other alternative). Olivia et al. (2009) provides more detailed discussion of the tests. 


\begin{tabular}{|c|c|c|c|c|c|c|c|}
\hline \multirow[t]{2}{*}{ gender } & 0.0143 & 0.0130 & 0.0127 & 0.00809 & 0.00870 & -0.108 & -0.214 \\
\hline & (0.0830) & (0.0820) & (0.0820) & (0.0824) & $(0.0862)$ & $(0.143)$ & $(0.145)$ \\
\hline \multirow[t]{2}{*}{ maritalstat } & $0.149 *$ & $0.147^{*}$ & $0.147^{*}$ & $0.151^{*}$ & $0.151^{*}$ & $0.336 * *$ & 0.138 \\
\hline & $(0.0886)$ & $(0.0876)$ & $(0.0876)$ & $(0.0878)$ & (0.0909) & $(0.134)$ & $(0.142)$ \\
\hline \multirow[t]{2}{*}{ educ } & $0.0279 * * *$ & $0.0284^{* * *}$ & $0.0284 * * *$ & $0.0282 * * *$ & $0.0304 * * *$ & $0.0745^{* * *}$ & $0.0256^{*}$ \\
\hline & $(0.00830)$ & $(0.00824)$ & $(0.00824)$ & $(0.00825)$ & $(0.00884)$ & $(0.0146)$ & $(0.0133)$ \\
\hline \multirow[t]{2}{*}{ formalwork } & $0.268 * * *$ & $0.272 * * *$ & $0.272 * * *$ & $0.271 * * *$ & $0.264 * * *$ & $0.209 * *$ & $0.308 * * *$ \\
\hline & $(0.0662)$ & $(0.0656)$ & $(0.0656)$ & $(0.0655)$ & $(0.0664)$ & (0.0996) & (0.0959) \\
\hline \multirow[t]{2}{*}{ houseowner } & $-0.129 *$ & $-0.136 * *$ & $-0.136 * *$ & $-0.131^{*}$ & $-0.124^{*}$ & -0.101 & $-0.468 * * *$ \\
\hline & (0.0681) & $(0.0681)$ & $(0.0680)$ & (0.0684) & $(0.0682)$ & (0.108) & (0.101) \\
\hline \multirow[t]{2}{*}{ urban } & $0.552 * * *$ & $0.572 * * *$ & $0.573 * * *$ & $0.545^{* * *}$ & $0.566 * * *$ & & \\
\hline & $(0.0811)$ & $(0.0856)$ & $(0.0850)$ & (0.0937) & $(0.102)$ & & \\
\hline \multirow[t]{2}{*}{ elevation } & $-0.0446 * * *$ & $-0.0449 * * *$ & $-0.0448 * * *$ & $-0.0426 * * *$ & $-0.0268^{*}$ & 0.00161 & $-0.0328^{*}$ \\
\hline & $(0.0113)$ & $(0.0112)$ & $(0.0112)$ & $(0.0115)$ & $(0.0147)$ & $(0.0461)$ & $(0.0176)$ \\
\hline \multirow[t]{2}{*}{ dcoast } & $0.437^{* *}$ & $0.455^{* *}$ & $0.457^{* *}$ & $0.471^{* *}$ & 0.336 & -1.287 & 0.316 \\
\hline & $(0.214)$ & $(0.213)$ & $(0.213)$ & $(0.214)$ & $(0.238)$ & $(0.966)$ & $(0.236)$ \\
\hline \multirow[t]{2}{*}{ w1x_hholdsize } & & & & & $-0.00568 * *$ & 0.0119 & $-0.710 * *$ \\
\hline & & & & & $(0.00224)$ & $(0.00726)$ & $(0.308)$ \\
\hline \multirow[t]{2}{*}{ w1x_age } & & & & & $0.00138^{*}$ & 0.00171 & $0.236 * * *$ \\
\hline & & & & & $(0.000759)$ & $(0.00134)$ & $(0.0515)$ \\
\hline \multirow[t]{2}{*}{ w1x_gender } & & & & & 0.00378 & $-0.237 * *$ & -4.112 \\
\hline & & & & & (0.0347) & $(0.105)$ & (3.702) \\
\hline \multirow[t]{2}{*}{ w1x_maritalstat } & & & & & 0.0315 & 0.00496 & 2.985 \\
\hline & & & & & (0.0393) & $(0.0630)$ & (3.011) \\
\hline \multirow[t]{2}{*}{ w1x_educ } & & & & & 0.00267 & $0.0266 * * *$ & -0.0315 \\
\hline & & & & & (0.00319) & $(0.00795)$ & $(0.296)$ \\
\hline \multirow[t]{2}{*}{ w1x_formalwork } & & & & & -0.0147 & $-0.0999 * * *$ & 2.331 \\
\hline & & & & & $(0.0211)$ & $(0.0368)$ & $(1.793)$ \\
\hline \multirow[t]{2}{*}{ w1x_houseowner } & & & & & 0.00887 & 0.00476 & $-5.899 * * *$ \\
\hline & & & & & $(0.0151)$ & $(0.0371)$ & $(1.876)$ \\
\hline \multirow[t]{2}{*}{ w1x_urban } & & & & & 0.0216 & & \\
\hline & & & & & (0.0151) & & \\
\hline \multirow[t]{2}{*}{ w1x_elevation } & & & & & -0.000854 & -0.000106 & 0.0696 \\
\hline & & & & & $(0.000830)$ & $(0.0111)$ & (0.0449) \\
\hline \multirow[t]{2}{*}{ w1x_dcoast } & & & & & -0.0255 & $-0.877 * *$ & -2.097 \\
\hline & & & & & $(0.0313)$ & $(0.362)$ & $(1.601)$ \\
\hline \multirow[t]{2}{*}{ constant } & $9.119 * * *$ & $9.143 * * *$ & $9.144 * * *$ & $9.160 * * *$ & $8.894 * * *$ & $7.870 * * *$ & $19.39 * * *$ \\
\hline & $(0.226)$ & $(0.227)$ & $(0.227)$ & $(0.229)$ & $(0.267)$ & $(0.543)$ & $(6.152)$ \\
\hline \multirow[t]{2}{*}{ Rho } & & -0.0000622 & & 0.000870 & $-0.00952^{*}$ & -0.0119 & $-1.510 * * *$ \\
\hline & & $(0.0000922)$ & & $(0.000930)$ & $(0.00573)$ & $(0.00865)$ & $(0.466)$ \\
\hline \multirow[t]{2}{*}{ Sigma } & & $0.607 * * *$ & $0.607 * * *$ & $0.606 * * *$ & $0.594 * * *$ & $0.534 * * *$ & $0.592 * * *$ \\
\hline & & (0.0194) & (0.0194) & (0.0194) & (0.0190) & $(0.0292)$ & $(0.0238)$ \\
\hline \multirow[t]{2}{*}{ Lambda } & & & -0.0000685 & -0.00111 & & & \\
\hline & & & $(0.0000963)$ & $(0.00126)$ & & & \\
\hline$N$ & 490 & 490 & 490 & 490 & 490 & 169 & 321 \\
\hline$R^{2}$ & 0.393 & 0.393 & 0.389 & 0.287 & 0.387 & 0.418 & 0.329 \\
\hline
\end{tabular}

Standard errors in parentheses. ${ }^{*} p<0.10,{ }^{* *} p<0.05,{ }^{* *} p<0.01$. Rho $\rho$ is the spatial autoregressive coefficient while Lambda $\lambda$ is the spatial autocorrelation coefficient.

Table 3 shows the model estimation results explaining income with the independent (RHS) variables (i.e. household characteristics, distance and location characteristics of households, and geographic variables). ${ }^{21}$ For comparison of models and approaches, we show results from the standard linear model (column 1), the four spatial models previously described (columns 2-5) and divide the sample into the urban and rural observations (columns 6-7) with the prefered SDM estimation method (equation 4).

The age of the household head (age), marital status of the household head (maritalstat), education level of the household head (educ), household head working in the formal sector (formalwork), living in the urban (urban), and the distant to the coast (dcoast)

\footnotetext{
${ }^{21}$ We classified Funafuti as the urban and outer-islands as rural since Funafuti is the capital and where the central government, commerce, main hospital, seaport and airport are located.
} 
were all highly significant with positive correlations with income. Household size (hholdsize), house owner (houseowner) and elevation (elevation) are also highly significant, but with negative correlations with income. ${ }^{22}$ The $\mathrm{R}^{2}$ for all models are $0.3-0.4$, at most explaining $40 \%$ of the variation in income across households. In this case, our diagnostic tests support the use of the SDM model. ${ }^{23}$ In terms of the geographic variables that will most likely be important when considering future changes in climatic conditions, we find that, ceteris paribus, poorer households locate in higher elevation areas in the outer islands, but in lower elevation in the main island of Funafuti (where we already observed the poor are on the narrower parts of the island). However, the distance to the coast variable, which is much more variable in the outer islands, will dominate any determination of income levels in these islands. Consistently, we find that the further that households locate from the coast, the higher their income is. For the urban area, our econometric specification does not yield statisitcally signficant results with respect to the geographic variables when the urban sample is exclusively estimated. However, the number of observations used in the regression is reduced dramatically, so this reflects, at least in part, the expected drop in statistical precision.

Table 4: Estimation Results - LHS poverty binary indicator (2010)

\begin{tabular}{lccc}
\hline & National & Urban & Rural \\
\hline hholdsize & $0.176^{* * *}$ & $0.162^{* * *}$ & $0.191^{* * *}$ \\
age & $(0.0264)$ & $(0.0386)$ & $(0.0390)$ \\
& -0.00116 & -0.00494 & 0.00340 \\
gender & $(0.00619)$ & $(0.0107)$ & $(0.00797)$ \\
& 0.0329 & 0.0943 & -0.0512 \\
maritalstatus & $(0.222)$ & $(0.343)$ & $(0.327)$ \\
& -0.141 & -0.432 & 0.0753 \\
educ & $(0.231)$ & $(0.350)$ & $(0.343)$ \\
& $-0.0517^{* *}$ & $-0.0786 * *$ & -0.0263 \\
formalwork & $(0.0222)$ & $(0.0339)$ & $(0.0311)$ \\
& $-0.654^{* * *}$ & -0.269 & $-1.110 * * *$ \\
houseowner & $(0.189)$ & $(0.279)$ & $(0.309)$ \\
& $0.461^{* *}$ & $0.464 *$ & 0.408 \\
urban & $(0.194)$ & $(0.267)$ & $(0.309)$ \\
& 0.264 & 0.0946 & 0.00669 \\
elevation & $(0.216)$ & $(0.566)$ & $(0.356)$ \\
dcoast & $0.0538^{*}$ & -0.00133 & $0.0943 * *$ \\
& $(0.0289)$ & $(0.0804)$ & $(0.0377)$ \\
Constant & -0.152 & 0.716 & -0.0899 \\
& $(0.558)$ & $(2.134)$ & $(0.597)$ \\
$N$ & $-2.064^{* * *}$ & -1.032 & $-3.040 * * *$ \\
\hline Standard errors in parenthe & $(0.593)$ & $1.010)$ & $(0.855)$ \\
& 490 & 169 & 321 \\
& & $0.05, * * * p<0.01$ &
\end{tabular}

\footnotetext{
${ }^{22}$ The elevation projected from the Digital Elevation Model (DEM) may differ marginally with land elevation. Variations between elevation and Mean Sea Level (MSL) is explained in http://www.esri.com/ news/arcuser/0703/geoid1of3.html

${ }^{23}$ Moran's I test is highly significant at $1 \%$ level, indicating spatial autocorrelation.
} 
Furthermore, we examined household characteristics that make households more likely or less likely to be in hardship. We used the probit model for all levels of national, rural and urban by regressing a binary dependent variable (poverty indicator, i.e. 1 if poor, else 0 ) with the same control variables we used for the linear income models. The estimation results in Table 4 shows that households with higher household size (hholdsize), reside on a higher elevation (elevation), and owned a house (houseowner) are more likely to be poor. Nevertheless, households with higher household head's level of education (educ) and with formal work (formalwork) are less likely to be poor.

We also replicate the same regressions after splitting the sample into urban and rural households to compare the differences in vulnerability and exposure. It generally shows very similar results with the national level, but with a few exceptions. The minor differences is the fact that the urban sample shows significant levels with a positive correlation between income and owning a house, a negative correlation between distance to the coast and income, and a positive correlation between land width and the household size.

Last, we used a panel of 130 households that we were able to identify in both the 2004/5 and 2010 HIES to estimate income and poverty; we estimated this model using both fixed- and random-effects models and present these results in the appendix. ${ }^{24}$ The results in appendix Table B3 shows that higher values of education (educ), higher distant to the coast (dcoast), migrating between islands (b_islands), household movements within islands ( $w_{-}$islands) and migrating to the urban (urban_mig), are associated with higher values of income. On the other hand, household size (hhsize) is associated with lower values of income. Similar results were obtained from the panel data models estimating the binary poverty indicator.

Statistics from the panel illustrate that a total of $26 \%$ of households migrated between islands where $85 \%$ are non-poor households. Non-poor households dominate movements between islands except for movements of households from the capital island Funafuti to the outer-islands where the poor represent $67 \%$. Table 6 shows that most of the movements within islands happen with the capital Funafuti as either source or destination. It is evident that the poor and low-income households move less both between and within islands. The domination in movements by non-poor households is due to higher access to human and financial capital that is required for these moves.

Table 6: Internal Migration of Households

\begin{tabular}{|c|c|c|c|c|}
\hline Movement type & $\begin{array}{c}\text { Households } \\
\text { that moved }\end{array}$ & $\begin{array}{c}\text { Non-poor } \\
\text { households } \\
\text { that moved }\end{array}$ & $\begin{array}{c}\text { Households } \\
\text { that moved to } \\
\text { wider land } \\
\text { width areas }\end{array}$ & $\begin{array}{c}\text { Households } \\
\text { that moved } \\
\text { closer to the } \\
\text { coast }\end{array}$ \\
\hline
\end{tabular}

\footnotetext{
${ }^{24}$ The Hausman panel test indicated a strong perference for the fixed-effects model over random-effects; while the Breusch-Pagan indicated the panel models are prefereable to the OLS estimation. However, we present all three specfications in the appendix for comparison.
} 


\begin{tabular}{|c|c|c|c|c|}
\hline & $\begin{array}{c}\text { (\% of } \\
\text { households in } \\
\text { source region) }\end{array}$ & $\begin{array}{c}\text { (\% of houses } \\
\text { that moved } \\
\text { from the } \\
\text { source region) }\end{array}$ & $\begin{array}{c}\text { (\% of houses } \\
\text { that moved } \\
\text { from the } \\
\text { source region) }\end{array}$ & $\begin{array}{c}\text { (\% of houses } \\
\text { that moved } \\
\text { from the } \\
\text { source region) }\end{array}$ \\
\hline Outer-islands to capital & 20 & 94 & 18 & 82 \\
\hline Capital to outer-islands & 12 & 33 & 100 & 0 \\
\hline Between outer-islands & 13 & 100 & 36 & 55 \\
\hline Within the capital & 20 & 90 & 80 & 60 \\
\hline Within outer-islands & 2 & 100 & 100 & 100 \\
\hline
\end{tabular}

Source: Authors' calculations from the $2004 / 5$ and 2010 HIES data.

There are more movements from the outer-islands to the capital Funafuti and within the capital itself. Unlike the capital Funafuti, the fewer movements in the outer islands is due to a few rented houses. Some of the reasons for frequent movements of households on Funafuti are civil servants moving between government houses or rented houses, civil servants on long-term training overseas availing their government or rented houses for others, civil servants elevating in their work positions moving to higher level government houses or move to higher rented houses. Government houses on Funafuti are closer to the center of the island which is the wider part of the island in terms of land width. Household movements to the outer-islands is mainly due to those who are retiring civil servants, those who cannot find work in the capital, and professionals (teachers, nurses, police) who have to relocate for work from one island to another. ${ }^{25}$ All outer-islands have primary schools and clinics. The main secondary school is located in the outer-islands on Vaitupu Island. It is evident that not only are the poor or low-income households more vulnerable and exposed to climatic disasters, they have less capacity for movements within and between islands.

\section{Conclusion}

Hardship is a challenge that merits the attention of policy makers in the Pacific. Our findings indicate that poverty has increased in Tuvalu over the past decade, but other potential measures of hardship and vulnerability show a decrease over time. However, we can confidently conclude that hardship levels are higher in the urban area (Funafuti) compared to the rural outer islands. The proportion of households who are potentially vulnerable to falling into hardship if there is a shock is also higher in the urban area and increasing.

In general, households on the urban region of Funafuti are also more exposed and vulnerable to disasters, once we account for their proximity and direction of exposure to the coast, and elevation. We also find that not only are the poor more likely to reside in areas prone to disasters in both the rural islands and the capital, they also tend to migrate less compared to non-poor households. This observation may end up being important in the future if migration becomes the only viable adaptation option to sea level rise (as many observers foresee).

\footnotetext{
${ }^{25}$ All outer-islands have primary schools, clinics and police stations. The main boarding secondary school is located in the outer-island on Vaitupu.
} 


\section{Bibliography}

Abbott, D. and Pollard, S. (2004). Hardship and Poverty in the Pacific. Asian Development Bank, Philippines.

ADB (2007). 2006 Tuvalu Economic Report: From Plan to Action. Pacific Study Series. Asian Development Bank, Philippines.

Anselin (1988). Spatial Econometrics: Methods and Models. Kluwer Academics, Dordrecht.

Anselin, L., Bera, A. K., Florax, R., and Yoon, M. J. (1996). Simple diagnostic tests for spatial dependence. Regional Science and Urban Economics, 26(1):77-104.

Becker, M., Meyssignac, B., Letetrel, C., Llovel, W., Cazenave, A., and Delcroix, T. (2012). Sea level variations at tropical Pacific islands since 1950. Global and Planetary Change, 8081:85-98.

Briguglio, L. (1997). Small island developing states and their economic vulnerabilities. Scope-Scientific Committee on Problems of the Environment International Council of Scientific Unions, 58:210-215.

Cabezon, Ezequiel, Leni Hunter, Patrizia Tumbarello, Kazuaki Washimi, and Yiqun Wu. 2015. Enhancing Macroeconomic Resilience to Natural Disasters and Climate Change in the Small States of the Pacific. IMF Working Paper WP/15/125.

Cavallo, E. and Noy, I. (2011). Natural Disasters and the Economy - A Survey. International Review of Environmental and Resource Economics, 5(1):63-102.

Christenson, E., Elliott, M., Banerjee, O., Hamrick, L., and Bartram, J. (2014). ClimateRelated Hazards: A Method for Global Assessment of Urban and Rural Population Exposure to Cyclones, Droughts, and Floods. International Journal of Environmental Research and Public Health, 11(2):2169-2192.

Dasgupta, A. and Baschieri, A. (2010). Vulnerability to climate change in rural Ghana: Mainstreaming climate change in poverty-reduction strategies. Journal of International Development, 22(6):803-820.

Dercon, S. (2005). Risk, Poverty and Vulnerability in Africa. Journal of African Economies, 14(4):483-488.

Dutta, I., Foster, J., and Mishra, A. (2011). On measuring vulnerability to poverty. Social Choice and Welfare, 37(4):743-761.

Ebi, K. L. and Bowen, K. (2016). Extreme events as sources of health vulnerability: Drought as an example. Weather and Climate Extremes, 11:95-102. 
Echevin, D. (2014). Characterising Vulnerability to Poverty in Rural Haiti: A Multilevel Decomposition Approach. Journal of Agricultural Economics, 65(1):131-150.

Elhorst, J. P. (2014). Spatial Econometrics. SpringerBriefs in Regional Science. Springer Berlin Heidelberg, Berlin, Heidelberg.

Gibson, J. and McKenzie, D. (2007). Using the global positioning system in household surveys for better economics and better policy. World Bank Policy Research Working Paper, (4195).

Gibson, J. and Rozelle, S. (2002). Poverty and access to infrastructure in Papua New Guinea.

Hallegatte, Stephane, Bangalore, Mook, Bonzanigo, Laura, Fay, Marianne, Kane, Tamaro, Narloch, Ulf, Rozenberg, Julie, Treguer, David, Vogt-Schilb, Adrien. 2016. Shock Waves : Managing the Impacts of Climate Change on Poverty. Washington, DC: World Bank.

Haughton, J. and Khandker, S. (2009). Handbook on Poverty and Inequality. The World Bank.

Jalan, J. and Ravallion, M. (1998). Are there dynamic gains from a poor-area development program? Journal of public economics, 67(1):65-85.

Jalan, J. and Ravallion, M. (2002). Geographic poverty traps? A micro model of consumption growth in rural China. Journal of Applied Econometrics, 17(4):329-346.

Jha, R. and Dang, T. (2010). Vulnerability to Poverty in Papua New Guinea in 1996: Vulnerability to Poverty in Papua New Guinea. Asian Economic Journal, 24(3):235-251.

Jha, R., Dang, T., and Sharma, K. L. (2009). Vulnerability to Poverty in Fiji. International Journal of Applied Econometrics and Quantitative Studies, 6(1):43-60.

LeSage, J. and Pace, R. K. (2009). Introduction to Spatial Econometrics. Taylor \& Francis Group.

Milcher, S. (2010). Household vulnerability estimates of Roma in Southeast Europe. Cambridge Journal of Economics, 34(4):773-792.

Murlindharan, T., Durgaprasad, J., and Rao, T. A. (1997). Knowledge-based expert system for damage assessment and vulnerability analysis of structures subjected to cyclones. Journal of Wind Engineering and Industrial Aerodynamics, 72:479-491.

Nadiruzzaman, M. and Wrathall, D. (2015). Participatory exclusion Cyclone Sidr and its aftermath. Geoforum, 64:196-204.

Noy (2015). Disasters in the Pacific: An Overview of Economic and Fiscal Issues. Pacific Economic Monitor, Asian Development Bank, July. 
Noy (2016). Natural Disasters in the Pacific Island Countries: New Measurements of Impacts. Natural Hazards, http://link.springer.com/article/10.1007/s11069-015-1957-6.

Olivia, S., Gibson, J., Rozelle, S., Huang, J., and Deng, X. (2011). Mapping poverty in rural China: how much does the environment matter? Environment and Development Economics, 16(02):129-153.

Olivia, S., Gibson, J., Smith, A., Rozelle, S., and Deng, X. (2009). An Empirical Evaluation of Poverty Mapping Methodology: Explicitly Spatial versus Implicitly Spatial Approach. In A Contributed Paper to the Australian Agricultural \& Resource Economics Societys Annual Conference, Cairns.

Ravallion, M. (1998). Poverty Lines in Theory and Practice. LSMS Working Paper No.133. World Bank, Washington D.C.

Walsh, K. J., McInnes, K. L., and McBride, J. L. (2012). Climate change impacts on tropical cyclones and extreme sea levels in the South Pacific: A regional assessment. Global and Planetary Change, 80-81:149-164.

World Bank (2007). Poverty and the Environment: Understanding Linkages at the Household Level. The World Bank, Washington D.C.

World Bank (2009). World Development Report 2010: Development and Climate Change. The World Bank, Washington D.C.

World Bank (2013). World Development Report 2014: Risk and Opportunity - Managing Risk for Development. The World Bank, Washington D.C.

World Bank (2014). Hardship and Vulnerability in the Pacific Island Countries. The World Bank, Washington D.C.

World Bank (2016). Climate and Disaster Resilience. Background paper for the Pacific Possible project.

World Bank and United Nations (2010). Natural Hazards, UnNatural Disasters: The Economics of Effective Prevention. The World Bank, Washington D.C.

Yamano, H., Kayanne, H., Yamaguchi, T., Kuwahara, Y., Yokoki, H., Shimazaki, H., and Chikamori, M. (2007). Atoll island vulnerability to flooding and inundation revealed by historical reconstruction: Fongafale Islet, Funafuti Atoll, Tuvalu. Global and Planetary Change, 57(3-4):407-416. 


\section{Appendix Table A: Description of Variables}

\begin{tabular}{|c|c|c|c|}
\hline No. & Variable & Description & Source \\
\hline 1 & linc & Logarithm of income per person. & \multirow{10}{*}{$\begin{array}{c}\text { Authors' calculations based } \\
\text { on household data from the } \\
\text { Central Statistics Division } \\
\text { (CSD), Government of } \\
\text { Tuvalu. }\end{array}$} \\
\hline 2 & hholdsize & Number of persons in the household. & \\
\hline 4 & age & Years of age of the household head. & \\
\hline 5 & gender & $\begin{array}{l}\text { Gender of the household head. Dummy, takes the } \\
\text { value of } 1 \text { if the household head is a male, otherwise } 0 .\end{array}$ & \\
\hline 6 & maritalstat & $\begin{array}{c}\text { Marital status of the household head. Dummy, takes } \\
\text { the value of } 1 \text { if the household head is married, } \\
\text { otherwise } 0 .\end{array}$ & \\
\hline 7 & ethnic & $\begin{array}{c}\text { The ethnicity of the household head, whether is a } \\
\text { Tuvaluan or not. Dummy, takes the value of } 1 \text { if the } \\
\text { household head is from Tuvalu, otherwise } 0 .\end{array}$ & \\
\hline 8 & lit & $\begin{array}{c}\text { Household head potential to read and write in both } \\
\text { English and Tuvaluan languages. Dummy, takes the } \\
\text { value of } 1 \text { if the household head knows both Tuvalu \& } \\
\text { English, otherwise } 0 .\end{array}$ & \\
\hline 9 & educ & Years of education of the household head. & \\
\hline 10 & formalwork & $\begin{array}{c}\text { Dummy, } 1 \text { if the household head works in the formal } \\
\text { sector, otherwise } 0 .\end{array}$ & \\
\hline 11 & houseowner & $\begin{array}{l}\text { Dummy, takes the value of } 1 \text { if the household head } \\
\text { owns a house, otherwise } 0 .\end{array}$ & \\
\hline 12 & urban & $\begin{array}{c}\text { The capital island Funafuti is referred to as urban while } \\
\text { rural refers to all the outer islands. Dummy, takes the } \\
\text { value of } 1 \text { when the household is in the urban, } \\
\text { otherwise } 0 .\end{array}$ & \multirow{10}{*}{$\begin{array}{c}\text { Authors' calculations based } \\
\text { on GPS locations of } \\
\text { households using reference } \\
\text { system UTM Zone S60 with } \\
\text { elipsoid WGS } 84 \text { and the } \\
\text { Digital Elevation Model } \\
\text { (DEM). }\end{array}$} \\
\hline 13 & d_cent & $\begin{array}{l}\text { Distant of the household to the Central in meters. This } \\
\text { was calculated from the household Geographical } \\
\text { Position System (GPS) location of the household to the } \\
\text { Government Building on Funafuti island. }\end{array}$ & \\
\hline 14 & d_pri & $\begin{array}{l}\text { Distant to the nearest Primary school in kilometers } \\
\qquad(\mathrm{km})\end{array}$ & \\
\hline 15 & d_hosp & Distant to the nearest Hospital and or Clinic in km. & \\
\hline 16 & d_govt & $\begin{array}{c}\text { Distant to the Government and Commercial area at } \\
\text { the capital Funafuti in } \mathrm{km} \text {. }\end{array}$ & \\
\hline 17 & dwide & Distant from lagoon-coast to the sea-coast in $\mathrm{km}$. & \\
\hline 18 & dcoast & Distant to the nearest coastline in kilometers. & \\
\hline 19 & d_pits & Distant to the nearest borrow pits and ponds in $\mathrm{km}$. & \\
\hline 20 & density & Population per kilometer square. & \\
\hline 21 & elevation & Elevation in meters. & \\
\hline 22 & b_islands & Dummy, 1 if household moved between islands. & \multirow{5}{*}{$\begin{array}{l}\text { Additional variables for } \\
\text { panel data. Authors' } \\
\text { calculations based on GPS } \\
\text { household locations \& } \\
\text { household data for } 2004 / 5 \\
\text { and } 2010 \text { from CSD. }\end{array}$} \\
\hline 23 & w_islands & Dummy, 1 if household moved within islands. & \\
\hline 24 & urban_mig & $\begin{array}{c}\text { Dummy, } 1 \text { if household moved from outer-islands to } \\
\text { the capital. }\end{array}$ & \\
\hline 25 & migrate_oi & Dummy, 1 if household moved between outer-islands. & \\
\hline 26 & rural_mig & $\begin{array}{l}\text { Dummy, } 1 \text { if household moved from the capital to the } \\
\text { outer-islands. }\end{array}$ & \\
\hline
\end{tabular}


Appendix B: Panel data models estimating income

\begin{tabular}{|c|c|c|c|c|c|c|}
\hline & $\begin{array}{c}\text { Pooled } \\
\text { OLS }\end{array}$ & $\begin{array}{l}\text { Fixed } \\
\text { Effects }\end{array}$ & $\begin{array}{l}\text { Random } \\
\text { Effects }\end{array}$ & $\begin{array}{c}\text { Pooled } \\
\text { OLS }\end{array}$ & $\begin{array}{l}\text { Fixed } \\
\text { Effects }\end{array}$ & $\begin{array}{l}\text { Random } \\
\text { Effects }\end{array}$ \\
\hline educ & $\begin{array}{c}0.0541 * * * \\
(0.0120)\end{array}$ & $\begin{array}{c}0.0696 * * * \\
(0.0263)\end{array}$ & $\begin{array}{c}0.0544 * * * \\
(0.0129)\end{array}$ & $\begin{array}{c}0.0593 * * * \\
(0.0119)\end{array}$ & $\begin{array}{c}0.0587^{* *} \\
(0.0255)\end{array}$ & $\begin{array}{c}0.0590 * * * \\
(0.0129)\end{array}$ \\
\hline hhsize & $\begin{array}{c}-0.0611^{* * *} \\
(0.0158)\end{array}$ & $\begin{array}{c}-0.0939 * * * \\
(0.0287)\end{array}$ & $\begin{array}{c}-0.0676 * * * \\
(0.0164)\end{array}$ & $\begin{array}{c}-0.0564 * * * \\
(0.0161)\end{array}$ & $\begin{array}{c}-0.0965^{* * *} \\
(0.0277)\end{array}$ & $\begin{array}{c}-0.0638 * * * \\
(0.0167)\end{array}$ \\
\hline sex & $\begin{array}{c}0.164 \\
(0.112)\end{array}$ & $\begin{array}{c}-0.474 * * \\
(0.236)\end{array}$ & $\begin{array}{l}0.0822 \\
(0.120)\end{array}$ & $\begin{array}{c}0.145 \\
(0.112)\end{array}$ & $\begin{array}{l}-0.333 \\
(0.237)\end{array}$ & $\begin{array}{l}0.0575 \\
(0.121)\end{array}$ \\
\hline age & $\begin{array}{l}0.000648 \\
(0.00311)\end{array}$ & $\begin{array}{l}-0.00131 \\
(0.00699)\end{array}$ & $\begin{array}{l}0.000191 \\
(0.00336)\end{array}$ & $\begin{array}{l}0.000428 \\
(0.00314)\end{array}$ & $\begin{array}{l}-0.00551 \\
(0.00701)\end{array}$ & $\begin{array}{l}-0.000183 \\
(0.00342)\end{array}$ \\
\hline ethnic & $\begin{array}{c}0.186 \\
(0.205)\end{array}$ & $\begin{array}{c}0.00472 \\
(0.614)\end{array}$ & $\begin{array}{c}0.147 \\
(0.226)\end{array}$ & $\begin{array}{c}0.156 \\
(0.208)\end{array}$ & $\begin{array}{c}0.219 \\
(0.593)\end{array}$ & $\begin{array}{c}0.117 \\
(0.231)\end{array}$ \\
\hline dcoast & $\begin{array}{c}0.000283 \\
(0.000195)\end{array}$ & $\begin{array}{c}0.000609 * * \\
(0.000305)\end{array}$ & $\begin{array}{l}0.000350 * \\
(0.000200)\end{array}$ & $\begin{array}{c}0.000243 \\
(0.000198)\end{array}$ & $\begin{array}{c}0.000716 * * \\
(0.000300)\end{array}$ & $\begin{array}{l}0.000352 * \\
(0.000203)\end{array}$ \\
\hline dwide & $\begin{array}{c}-0.00022 * * * \\
(0.0000569)\end{array}$ & $\begin{array}{c}-0.000170 \\
(0.000115)\end{array}$ & $\begin{array}{c}-0.00021 * * * \\
(0.0000610)\end{array}$ & $\begin{array}{c}-0.00021 * * * \\
(0.0000591)\end{array}$ & $\begin{array}{l}0.0000808 \\
(0.000148)\end{array}$ & $\begin{array}{c}-0.00018 * * * \\
(0.0000651)\end{array}$ \\
\hline b_islands & $\begin{array}{c}0.199 \\
(0.120)\end{array}$ & $\begin{array}{c}0.419 * * * \\
(0.145)\end{array}$ & $\begin{array}{c}0.251^{* *} \\
(0.115)\end{array}$ & & & \\
\hline w_islands & $\begin{array}{c}0.499 * * * \\
(0.190)\end{array}$ & $\begin{array}{c}0.139 \\
(0.227)\end{array}$ & $\begin{array}{c}0.426 * * \\
(0.181)\end{array}$ & & & \\
\hline urban_mig & & & & $\begin{array}{c}0.211 \\
(0.171)\end{array}$ & $\begin{array}{c}0.982 * * * \\
(0.253)\end{array}$ & $\begin{array}{c}0.347^{* *} \\
(0.167)\end{array}$ \\
\hline migrate_oi & & & & $\begin{array}{l}0.363^{*} \\
(0.196)\end{array}$ & $\begin{array}{c}0.267 \\
(0.226)\end{array}$ & $\begin{array}{l}0.328 * \\
(0.186)\end{array}$ \\
\hline rural_mig & & & & $\begin{array}{l}-0.305 \\
(0.268)\end{array}$ & $\begin{array}{l}-0.346 \\
(0.372)\end{array}$ & $\begin{array}{l}-0.210 \\
(0.258)\end{array}$ \\
\hline _cons & $\begin{array}{c}3.675^{* * *} \\
(0.287)\end{array}$ & $\begin{array}{c}4.393 * * * \\
(0.639)\end{array}$ & $\begin{array}{c}3.812^{* * *} \\
(0.305)\end{array}$ & $\begin{array}{c}3.682 * * * \\
(0.289)\end{array}$ & $\begin{array}{c}4.115^{* * *} \\
(0.619)\end{array}$ & $\begin{array}{c}3.809 * * * \\
(0.308)\end{array}$ \\
\hline$N$ & 260 & 260 & 260 & 260 & 260 & 260 \\
\hline$R^{2}$ & 0.236 & 0.327 & 0.263 & 0.228 & 0.365 & 0.277 \\
\hline
\end{tabular}

Standard errors in parentheses

${ }^{*} p<0.10,{ }^{* *} p<0.05, * * * p<0.01$

Source: Authors' estimations from $2004 / 5$ and 2010 HIES data 


\section{Appendix C: Sea levels}

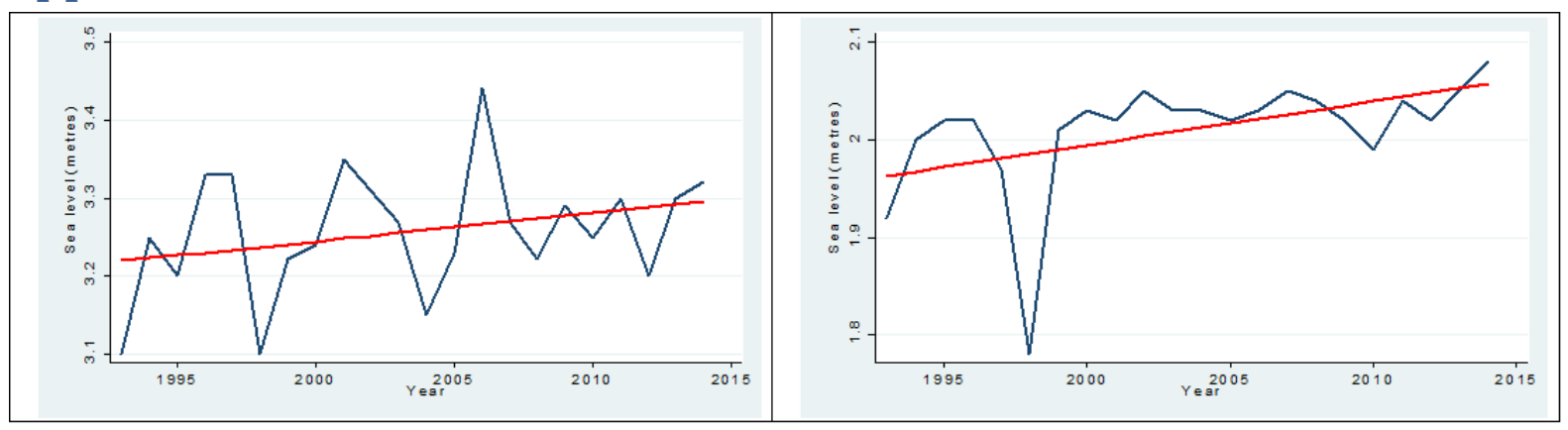

Notes: The left panel shows the maximum sea levels on Funafuti (Tuvalu) from 1993 to 2014. Author's calculations, on data from the Tuvalu Meteorological Service (TMS). The floods cause sea water to come from the ground in the inner parts of Funafuti Island. From 1993 to 2002, the average number of times the sea level rose above 3 meters is 8 per year, and 10 for 2003 to 2012. The right panel shows the mean sea level on Funafuti (Tuvalu) from 1993 to 2014. 


\section{Appendix D: Hardship maps}

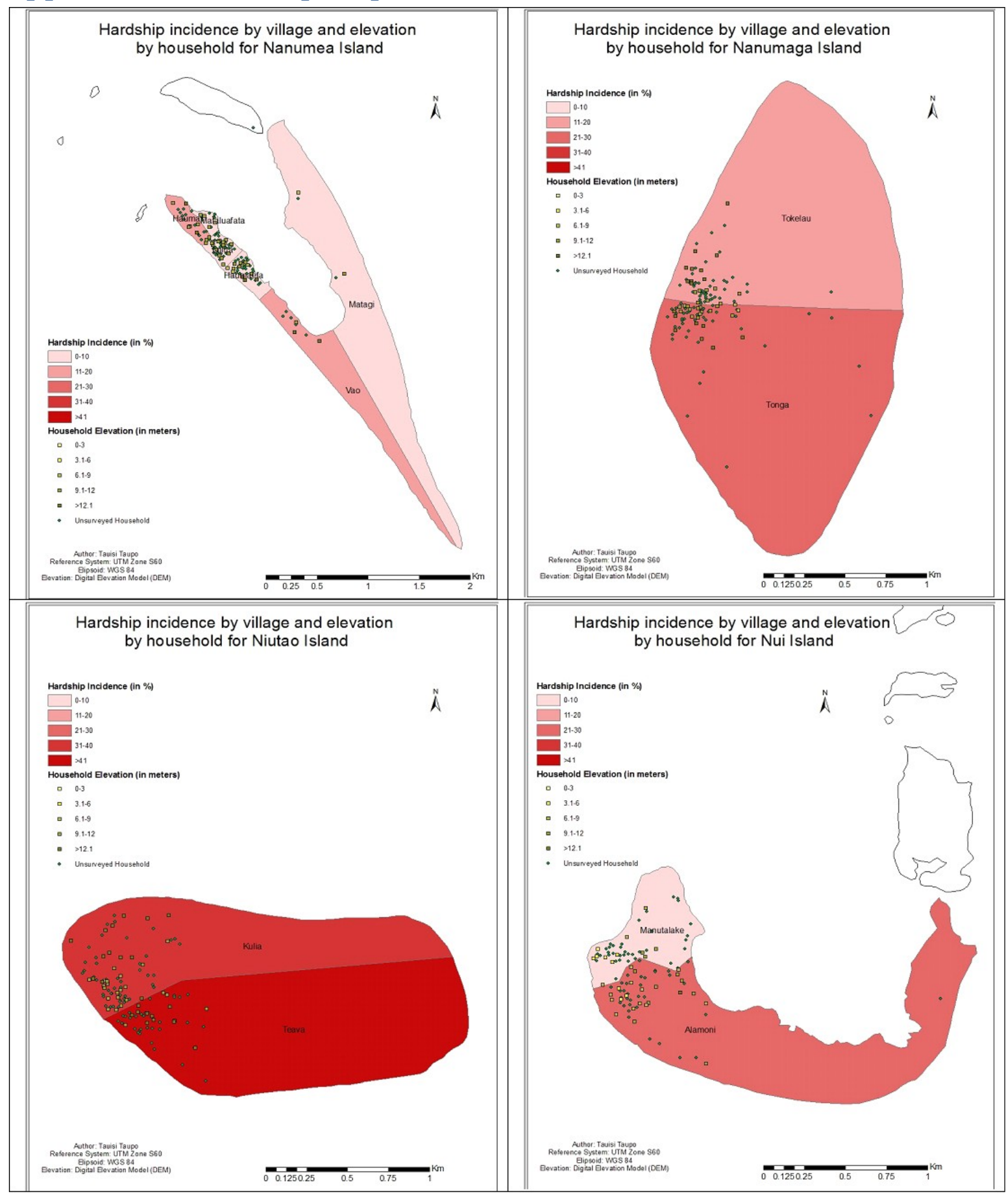

Source: Authors' digitized maps.

Figure D1: Hardship incidence in the Northern Islands. 


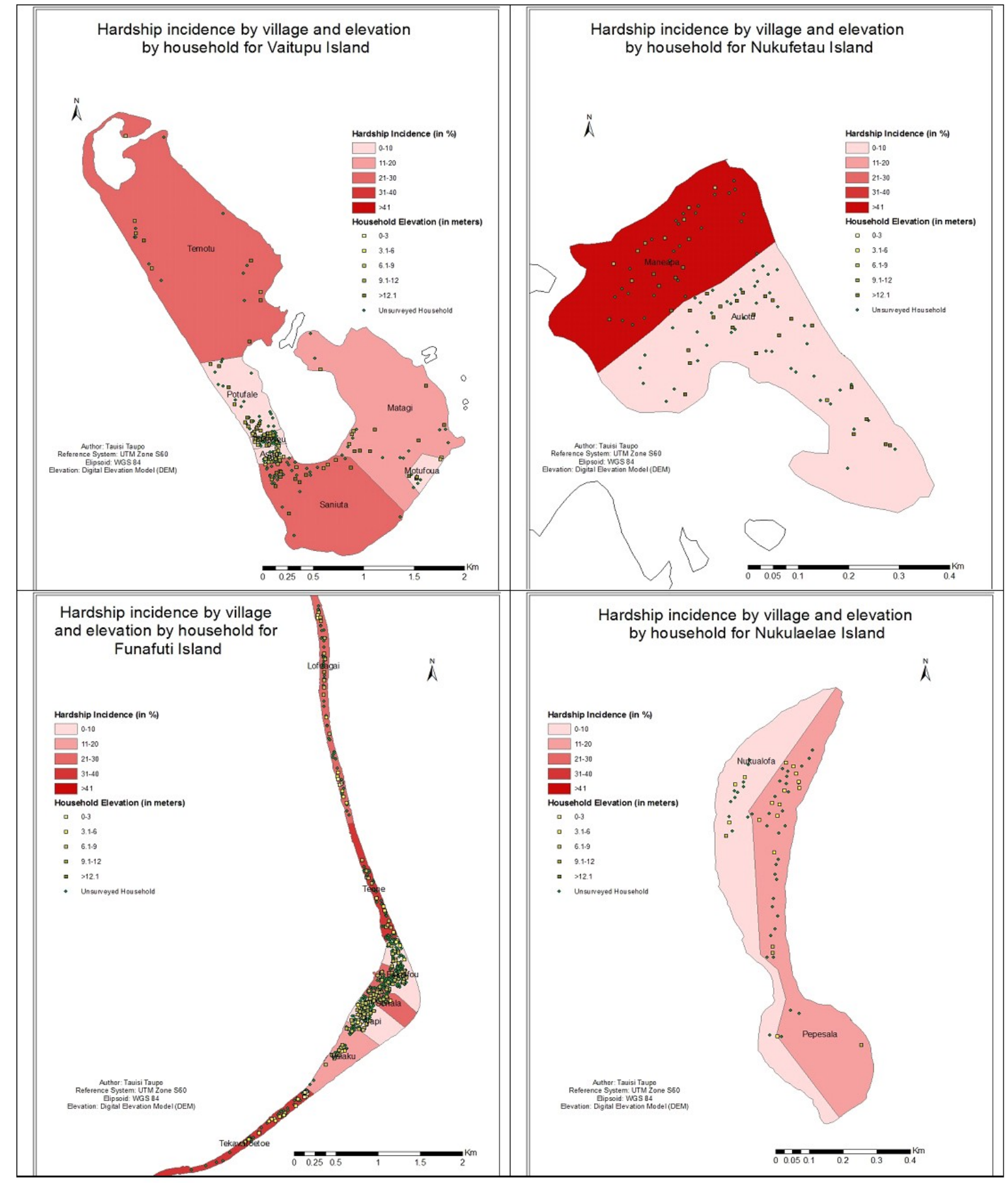

Source: Authors' digitized maps.

Figure D2: Hardship incidence in the Southern Islands. 


\section{Appendix E: Elevation maps}

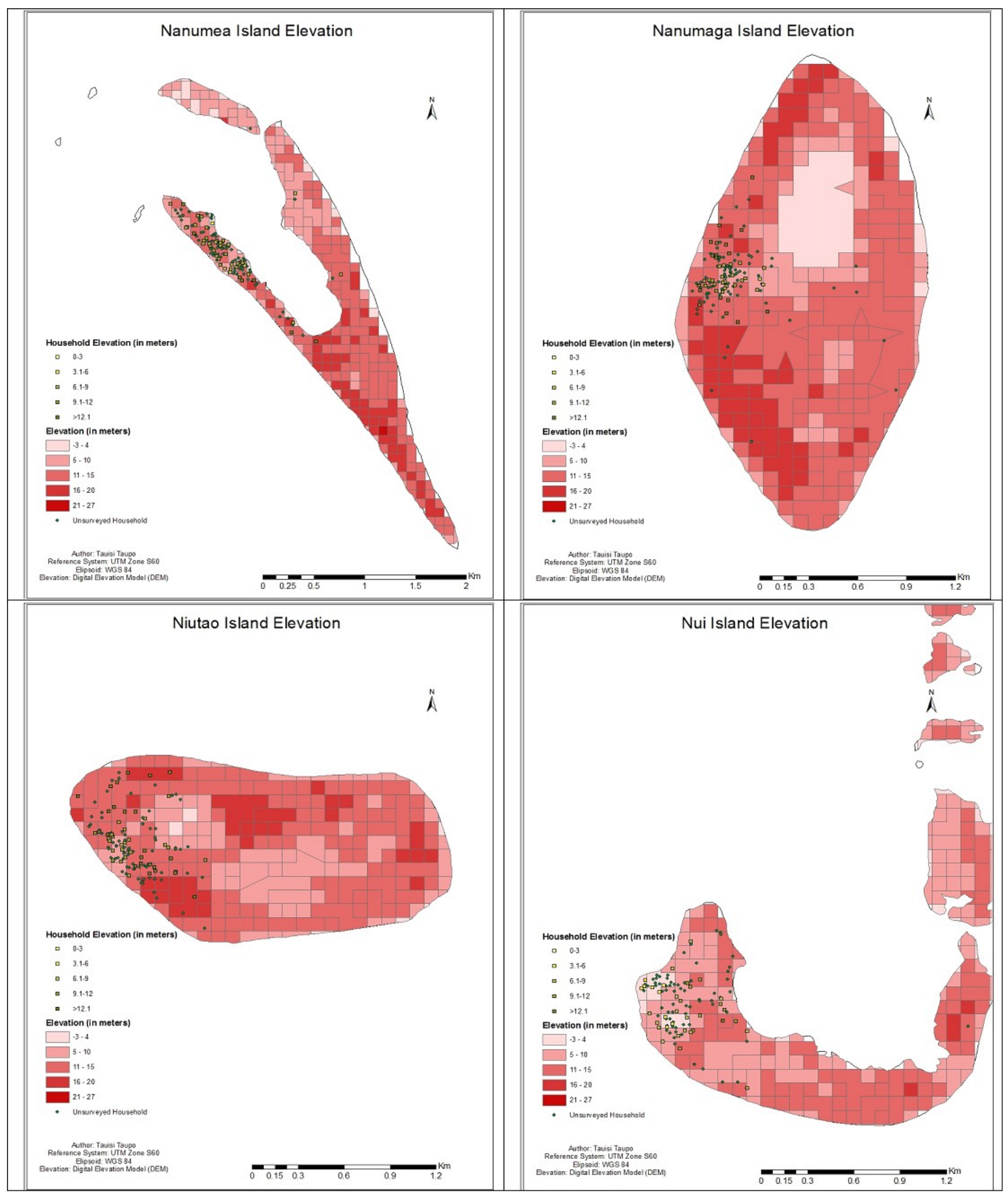

Source: Authors' digitized maps.

Figure E1: Elevation in the Northern Islands. 


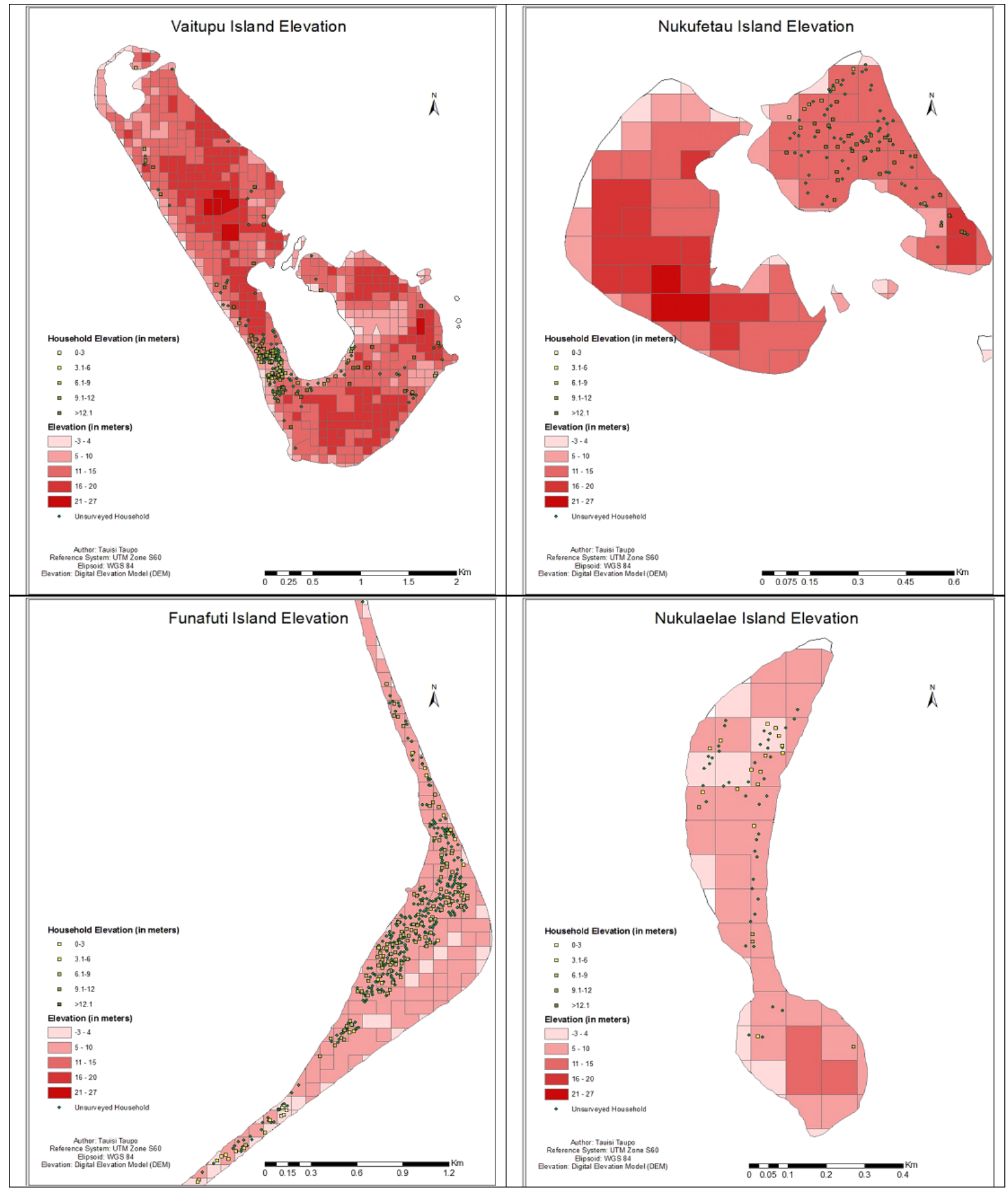

Source: Authors' digitized maps.

Figure E2: Elevation in the Southern Islands. 